\title{
Quantitative Phosphoproteome Analysis of Clostridioides difficile Toxin B Treated Human Epithelial Cells
}

\author{
Johannes Junemann, Ingo Just, Ralf Gerhard and Andreas Pich* \\ Hannover Medical School, Institute for Toxicology, Hanover, Germany
}

The large clostridial glucosylating toxin $B(T c d B)$ is a major virulence factor of the nosocomial pathogen Clostridioides difficile. TcdB inhibits small GTPases by glucosylation leading to impaired downstream signaling. TcdB also possesses a glucosyltransferase independent effect described as pyknosis. To elucidate the impact of TcdB and its glucosylation-inactive mutant $T_{c d B} B_{N N}$ on the kinome of human cells, SILAC labeled HEp-2 cells were treated with $2 \mathrm{nM}$ TcdB for $8 \mathrm{~h}$. Phosphopeptides were enriched using SCX chromatography, IMAC and $\mathrm{TiO}_{2}$ followed shotgun mass

OPEN ACCESS

Edited by:

Miguel Cacho Teixeira,

Universidade de Lisboa, Portugal

Reviewed by:

Philip R. Hardwidge,

Kansas State University, United States

Raquel Hontecillas,

Virginia Tech, United States

${ }^{*}$ Correspondence:

Andreas Pich

pich.andreas@mh-hannover.de

Specialty section:

This article was submitted to Infectious Diseases,

a section of the journal

Frontiers in Microbiology

Received: 15 June 2018 Accepted: 29 November 2018 Published: 17 December 2018

Citation: Junemann J, Just I, Gerhard R and Pich A (2018) Quantitative

Phosphoproteome Analysis of Clostridioides difficile Toxin B Treated Human Epithelial Cells.

Front. Microbiol. 9:3083. doi: 10.3389/fmicb.2018.03083 spectrometry analysis. Overall 4,197 phosphopeptides were identified; more than 1,200 phosphosites responded to treatment with $T c d B$ or $T c d B_{N X N}$. The data suggested that predominantly stress-activated MAPK-dependent signaling pathways were triggered by toxin B treatment.

Keywords: Clostridioides difficile, phosphoproteome, shotgun proteomics, small GTPases, TcdB

\section{INTRODUCTION}

Clostridioides difficile is one of the most common human nosocomial pathogens and causes antibiotic-associated diarrhea leading sometimes to severe pseudomembranous colitis (Loo et al., 2005; Voth and Ballard, 2005). The main virulence factors are C. difficile toxin A (TcdA) and toxin B (TcdB) (Just and Gerhard, 2004). They both belong to the clostridial glucosylating toxins (CGT) that inactivate small GTPases by transferring a glucose moiety to a highly conserved threonine residue (Thr-35 in Rho and Thr-37 in Rac/Cdc42) (Just et al., 1995), while TcdB is up to 1,000 times more potent than TcdA (Chaves-Olarte et al., 1997). In case of TcdB Rho, Rac, and Cdc42 are glucosylated causing a perturbed downstream signaling of the affected small GTPases (Kuehne et al., 2010; Zeiser et al., 2013; Genth et al., 2014). This leads initially to a rearrangement of the cytoskeleton and cell cycle arrest (cytopathic effect) (Reinert et al., 2005; Halabi-Cabezon et al., 2008) and finally to apoptosis (cytotoxic effect) (Matarrese et al., 2007). Recently, it has been shown that high concentrations of TcdB, but not TcdA, have an additional effect causing necrotic cell death termed pyknosis (Farrow et al., 2013; Wohlan et al., 2014; Chumbler et al., 2016; Frädrich et al., 2016). This is manifested in morphological changes such as chromatin condensation, ballooning of the plasma membrane and loss of membrane integrity. Interestingly, this effect is also triggered by the glucosyltransferase-deficient mutant $\operatorname{TcdB}_{\mathrm{NXN}}$ and is therefore independent of small GTPase glucosylation (Wohlan et al., 2014). It has been suggested that ROS production and involvement of the NADPH oxidase complex are responsible for this effect. However, exact mechanisms of both 
effects - glucosyltransferase-dependent and independent - are still mostly unknown. Recently, several proteome studies have been conducted to investigate the impact on the proteome and to elucidate the affected downstream signaling pathways by TcdA and TcdB treatment with variating toxin concentrations (Zeiser et al., 2013; Jochim et al., 2014; Junemann et al., 2016; Erdmann et al., 2017). Both toxins exhibit similar effects on the proteome of human epithelial cells when using moderate toxin concentrations. Especially proteins associated with cytoskeleton organization, signaling, cell-cell contact and cell proliferation are significantly altered. Interestingly, these protein groups were also affected by inducing pyknosis with high $\mathrm{TcdB}_{\mathrm{NXN}}$ concentrations, except proteins involved in GTPase-related signaling.

In this study a comprehensive phosphoproteome study was conducted to further investigate the involved signaling pathways which are altered after $\mathrm{TcdB}$ and $\mathrm{TcdB}_{\mathrm{NXN}}$ treatment (Stasyk and Huber, 2012). Pyknosis-inducing conditions and the human epithelial cell line HEp-2 were chosen, in order to cover the glucosyltransferase-independent effect. With the use of SCX chromatography and IMAC and $\mathrm{TiO}_{2}$ phosphopeptide enrichment techniques in total more than 1,000 significantly altered phosphosites were identified which alterations shed more light on intracellular regulatory processes upon toxin treatment.

\section{MATERIALS AND METHODS}

\section{Cultivation of HEp-2 Cells and SILAC Labeling}

The human epithelial cell line HEp-2 was cultured in $75 \mathrm{~cm}^{2}$ flasks in a humidified $5 \% \mathrm{CO}_{2}$ atmosphere at $37^{\circ} \mathrm{C}$ and $95 \%$ humidity. Cells were cultivated in Minimum Essential Media (MEM) without arginine and lysine (Thermo Fisher Scientific, United States). The media was supplemented with $10 \%$ dialyzed bovine fetal calf serum (Silantes, Germany), $100 \mathrm{U} / \mathrm{ml}$ penicillin, $0.1 \mathrm{mg} / \mathrm{ml}$ streptomycin (Merck, Germany) and $0.4 \mathrm{mM}$ L-proline (Sigma, Germany) in order to avoid arginine-proline conversion (Lössner et al., 2011). For the metabolic labeling 0.6/0.4 mM Arg-0/Lys-0 (light), Arg-6/Lys-4 (medium), or Arg10/Lys-8 (heavy) (Silantes, Germany) were added according to SILAC protocol (Ong et al., 2002). Complete incorporation of stable isotope labeled amino acids was checked prior to experiments by LC-MS. Cells were passaged every 3-4 days at a 1:5 split ratio.

\section{Treatment of HEp-2 Cells and Sample Preparation}

At a confluency of $75 \%$ the differently labeled HEp-2 cells were treated with $2 \mathrm{nM}$ TcdB or $\mathrm{TcdB}_{\mathrm{NXN}}$ for $8 \mathrm{~h}$. Recombinant toxins were generated using the Bacillus megaterium expression system as previously described (Olling et al., 2011). Untreated cells cultured in SILAC-media were used as control. All experiments were carried out in triplicates including a label switch. Changes in cell morphology were documented by phase contrast microscopy (Zeiss, Germany). After treatment, cells were washed twice with ice cold PBS and subsequently harvested by scraping cells and dissolved in lysis buffer containing $50 \mathrm{mM}$ ammonium bicarbonate ( $\mathrm{pH} 8.0$ ), 8 M Urea, $1 \mathrm{mM}$ sodium ortho-vanadate, complete EDTA-free protease inhibitor cocktail (Roche) and phosSTOP phosphatase inhibitor cocktail (Roche). Cells were homogenized on ice by sonication and cell debris was removed by centrifugation at $16,000 \mathrm{~g}$ for $20 \mathrm{~min}$ at $4^{\circ} \mathrm{C}$ and total protein concentrations was determined using a Lowry assay (BioRad). Equal amounts $(1.3 \mathrm{mg})$ of differently labeled and treated lysates were combined as already described (Zeiser et al., 2013; Junemann et al., 2016).

\section{Protein Digestion and Fractionation by SCX}

Proteins were reduced with dithiothreitol (DTT) $(5 \mathrm{mM})$ for $1 \mathrm{~h}$ at $37^{\circ} \mathrm{C}$ and subsequently alkylated with iodoacetamide IAA $(10 \mathrm{mM})$ in the dark at room temperature for $30 \mathrm{~min}$. Alkylation was stopped by adding DTT at a final concentration of $5 \mathrm{mM}$. Lysates were diluted with $50 \mathrm{mM} \mathrm{ABC}$ to a final urea concentration below $4 \mathrm{M}$. Proteins first were digested with Lys-C (Wako) at a 1:150 enzyme/protein ratio for $4 \mathrm{~h}$ at $37^{\circ} \mathrm{C}$ and then trypsin (1:80; Promega) was added followed by an overnight incubation at $37^{\circ} \mathrm{C}$. Digestion was stopped by acidification with TFA to a final concentration of $1 \%$. Peptide solution was desalted using Sep-Pak tC18 cartridges (Waters) according to the manufacturer's protocol.

Dried peptides were dissolved in SCX Buffer A (7 mM $\mathrm{KH}_{2} \mathrm{PO}_{4}, \mathrm{pH} 2.65,30 \% \mathrm{ACN}$ ) and separated by strong cation exchange (SCX) using an Agilent 1200 HPLC equipped with a PolySULFOETHYL A column $(250 \mathrm{~mm} \times 9.4 \mathrm{~mm} ; 5 \mu \mathrm{m}$ beads, pore size 200Å) (259-SE0502, PolyLC Inc.). Chromatography was performed by increasing SCX Buffer B concentration (7 mM $\mathrm{KH}_{2} \mathrm{PO}_{4}, 350 \mathrm{mM} \mathrm{KCl}, \mathrm{pH} 2.65,30 \% \mathrm{ACN}$ ) from 1-30\% over $40 \mathrm{~min}$ at a flow rate of $2 \mathrm{ml} / \mathrm{min}$. Twelve 5 -min fractions were collected over the full run, lyophilized and subsequently desalted using Sep-Pak tC18 cartridges (Waters). Fractions 1/2, 3/4, and $11 / 12$ were pooled for phosphopeptide enrichment resulting in a total of 9 fractions.

\section{Phosphopeptide Enrichment}

A 2D affinity chromatography was conducted for phosphopeptide enrichment for each of the 9 fractions. In the first step peptides were subjected to an immobilized metal affinity chromatography using a Fe-NTA phosphopeptide enrichment kit according to the manufacturer's protocol (\#88300, Thermo Fisher Scientific). Eluted phosphopeptides were acidified by TFA to final concentration of $2.5 \%$ and dried by vacuum centrifugation. All flow-troughs after sample loading were pooled, dried by vacuum centrifugation and stored for subsequent enrichment step by metal oxide affinity chromatography (MOAC) using the $\mathrm{TiO}_{2}$ phosphopeptide enrichment spin tips (\#88303, Thermo Fisher Scientific). Spin tips were equilibrated by washing with Buffer A (80\% ACN/0.4\% TFA) first and then with Buffer B (57\% ACN/0.3\% TFA/25\% lactic acid). Peptides were suspended in Buffer B and applied to the spin tips. After reapplying samples, spin tips were again washed with Buffer B and three times with Buffer A before 
peptides were eluted with $1.5 \% \mathrm{NH}_{4} \mathrm{OH}$ first and then with $5 \%$ pyrrolidine. Eluted samples were acidified with TFA to a final concentration of $1.25 \%$ and dried by vacuum centrifugation. All IMAC and $\mathrm{TiO}_{2}$ elution fractions were cleaned up prior to MS analysis using graphite spin columns (\#88302, Thermo Fisher Scientific) according to the manufacturer's protocol.

\section{Liquid Chromatography Mass Spectrometry (LC-MS)}

Dried phosphopeptides were reconstituted in 2\% ACN/0.1\% TFA and analyzed by an Obritrap Velos mass spectrometer connected to an Ultimate 3000 RSLC nanoflow system (Thermo Fisher Scientific). Samples were loaded on a trap column $(2 \mathrm{~cm}$ length, $75 \mu \mathrm{m}$ ID, $3 \mu \mathrm{m}$ C18 particles) at a flow rate of $6 \mu \mathrm{l} / \mathrm{min}$ of $0.1 \%$ TFA for $5 \mathrm{~min}$. The trap column was switched in line with the analytical column (Acclaim PepMap, Thermo Fisher Scientific, $50 \mathrm{~cm}$ length, $75 \mu \mathrm{m}$ ID, $2 \mu \mathrm{m}$ C18 particles,) and peptides were eluted at a flow rate of $250 \mathrm{nl} / \mathrm{min}$ and at $45^{\circ} \mathrm{C}$ column temperature by an increasing multistep linear acetonitril gradient from 4 to $25 \%$ in $105 \mathrm{~min}$ and from 25 to $50 \%$ in the following $35 \mathrm{~min}$. The column outlet was directly connected to the nano electrospray source of the mass spectrometer and peptides were ionized with a spray voltage of $1.35 \mathrm{kV}$ using metal-coated fused silica emitter.

The Orbitrap Velos mass spectrometer was operated in datadependent acquisition mode recording survey scans in the orbitrap mass analyzer with a mass range from 300 to 1600 at a resolution of 60,000 at $\mathrm{m} / \mathrm{z} 400$. The five most intense precursors with a charge state of +2 or higher were selected for CID fragmentation with a normalized collision energy of 38 using multi-stage activation for the neutral loss masses of phosphoric acid and MS/MS spectra were acquired in the linear ion trap mass analyzer. Dynamic exclusion duration was set to $30 \mathrm{~s}$.

\section{Data Processing}

Raw data were processed with MaxQuant software (version 1.5.3.30) (Cox and Mann, 2008) and peptides were identified by searching against all human entries of the UniProtKB/SwissProt database using the Andromeda search engine (Cox et al., 2011). Propionamidation (C) was set as fixed modification and a maximum of two missed cleavages was allowed. Phosphorylation
(S/T/Y), oxidation (M), deamidation (N/Q) and acetylation (protein N-terminal) were set as variable modifications. A false discovery rate of 0.01 on peptide and protein level was used for identification and "re-quantify" and "match between runs" options were checked. For quantification a minimum ratio count of 1 was used and peptides had to be identified in at least 2 replicates for statistical analysis. Data were analyzed and visualized with the software tools Perseus (version 1.5.2.6) (Cox and Mann, 2012; Tyanova et al., 2016) and Cytoscape (version 3.4) Shannon et al., 2003). Two sided on-sample Student's $t$-test was applied for the comparison between TcdB vs. control and $\mathrm{TcdB}_{\mathrm{NXN}}$ vs. control.

\section{RESULTS}

\section{Altered Morphology by TcdB and TcdB $_{\text {NXN }}$ Treatment}

HEp-2 cells were used to elucidate the impact of TcdB and $\mathrm{TcdB}_{\mathrm{NXN}}$ on the phosphorylation status of cellular proteins designated as phosphoproteome. According to previous proteome studies cells were treated with a high toxin concentration of $2 \mathrm{nM}$ for $8 \mathrm{~h}$ to induce both, cell rounding and the pyknotic phenotype. After TcdB treatment most cells exhibited the typical cell rounding morphology (Figure 1) and about $20 \%$ of the cells showed the pyknotic morphology. The glucosyltransferase-deficient mutant $\mathrm{TcdB}_{\mathrm{NXN}}$ only revealed the pyknotic phenotype for almost all cells. No morphological changes were observed in the control.

\section{Quantitative Phosphoproteome Analysis After TcdB or TcdB NXN $_{\text {Treatment }}$}

The phosphoproteome was analyzed by using a SILAC triplex shotgun approach in combination with SCX and phosphopeptide enrichment by IMAC and $\mathrm{TiO}_{2}$ prior to MS analysis. With this technique in total 3,256 protein groups were identified by sequence identification of 12,447 peptides (Supplementary Tables 1, 2). Nearly 50\% of the identified proteins possessed at least one phosphorylation site (Figure 2A). A phosphorylation site was determined for 5,855 peptides (Figure 2B). Out of these phosphosites $73.2 \%$ were identified by IMAC and $26.8 \%$ by

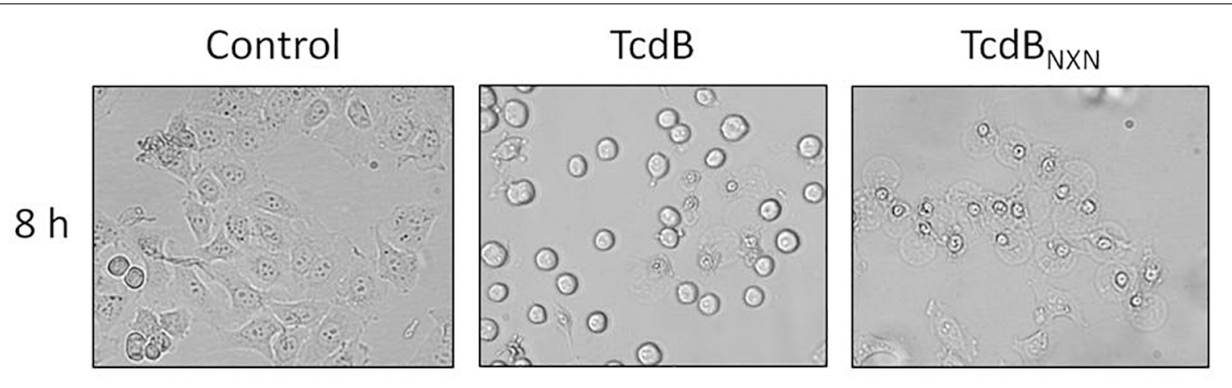

FIGURE 1 | Morphological changes after TcdB or TcdB ${ }_{N X N}$ treatment. Subconfluent HEp-2 cells were treated either with 2 nM TcdB or 2 nM TcdB ${ }_{N X N}$ for 8 h. Control cells were not treated and illustrate normal morphology. TcdB treatment led to typical rounding of most cells and also some pyknotic cells could be observed by phase-contrast microscopy; whereas in consequence of TcdB $\mathrm{NXN}_{\mathrm{N}}$ treatment all cells exhibited only pyknotic morphology, which was manifested by blistering and chromatin condensation. 
TABLE 1 | Top 10 up- and down-regulated phosphosites after $8 \mathrm{~h}$ treatment with TcdB.

\begin{tabular}{|c|c|c|c|c|c|c|c|}
\hline Uniprot ID & Gene name & Protein name & Peptide sequence & $\mathrm{g}_{2}$ Ratio TcdB/control & $p$-Value & Amino acid & Peptide score \\
\hline P05412 & JUN & $\begin{array}{l}\text { Transcription factor } \\
\text { AP-1 }\end{array}$ & NSDLLTㅁPDVGLLK & 4.18 & 2.05E-02 & S-63 & 200.33 \\
\hline MOQZO4 & ZFP36 & Tristetraprolin & STSLLVEGR & 3.85 & 4.77E-02 & S-67 & 123.79 \\
\hline P05412 & JUN & $\begin{array}{l}\text { Transcription factor } \\
\text { AP-1 }\end{array}$ & LAㅗPELER & 3.67 & $3.32 \mathrm{E}-03$ & S-73 & 111.27 \\
\hline Q9NQW6 & ANLN & $\begin{array}{l}\text { Actin-binding } \\
\text { protein anillin }\end{array}$ & NKAㅗPQSEFMPSK & 3.52 & $2.24 \mathrm{E}-04$ & S-792 & 127.49 \\
\hline Q09666 & AHNAK & $\begin{array}{l}\text { Neuroblast } \\
\text { differentiation- } \\
\text { associated protein } \\
\text { AHNAK }\end{array}$ & LK $\underline{\mathbf{S} E D G V E G D L G E T Q S R ~}$ & 3.40 & $3.32 \mathrm{E}-03$ & S-135 & 255.63 \\
\hline E5RJU9 & MTDH & Protein LYRIC & LSSQIㅁAGEEK & 3.26 & 8.28E-04 & S-275 & 117.2 \\
\hline G3V1T9 & RBM7 & $\begin{array}{l}\text { RNA-binding } \\
\text { protein } 7\end{array}$ & SFㅌSPENFQR & 3.19 & 9.30E-03 & S-16 & 125.36 \\
\hline P05412 & JUN & $\begin{array}{l}\text { Transcription factor } \\
\text { AP-1 }\end{array}$ & $\begin{array}{l}\text { LQALKEEPQTVP } \\
\text { EMPGETPPLSPIDMESQER }\end{array}$ & 3.02 & 9.36E-03 & $S-243$ & 83.944 \\
\hline K7EMZ9 & LSM14A & $\begin{array}{l}\text { Protein LSM14 } \\
\text { homolog A }\end{array}$ & 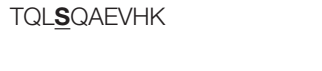 & 2.89 & 1.18E-02 & S-173 & 96.135 \\
\hline V9GYM8 & ARHGEF2 & $\begin{array}{l}\text { Rho guanine } \\
\text { nucleotide } \\
\text { exchange factor } 2\end{array}$ & SES彑LESPRGER & 2.88 & 1.31E-03 & S-690 & 145.81 \\
\hline Q09666 & AHNAK & $\begin{array}{l}\text { Neuroblast } \\
\text { differentiation- } \\
\text { associated protein } \\
\text { AHNAK }\end{array}$ & I $\underline{\mathbf{S} A P N V D F N L E G P K}$ & -4.56 & $2.13 \mathrm{E}-02$ & S-5448 & 188.9 \\
\hline Q9H7D0 & DOCK5 & $\begin{array}{l}\text { Dedicator of } \\
\text { cytokinesis protein } \\
5\end{array}$ & $\underline{\mathbf{s} L Q L M D N R}$ & -3.92 & 4.44E-03 & S-1766 & 130.1 \\
\hline Q9H3Q1 & CDC42EP4 & $\begin{array}{l}\text { Cdc42 effector } \\
\text { protein } 4\end{array}$ & AGEPDGESLDEQPSSSSSK & -3.79 & $4.23 \mathrm{E}-02$ & S-64 & 192.16 \\
\hline Q9H2G2 & SLK & $\begin{array}{l}\text { STE20-like } \\
\text { serine/threonine- } \\
\text { protein } \\
\text { kinase }\end{array}$ & RA్SDLSIASSEEDK & -3.43 & 3.03E-02 & S-340 & 228.65 \\
\hline Q5VZK9 & LRRC16A & $\begin{array}{l}\text { Leucine-rich } \\
\text { repeat-containing } \\
\text { protein } 16 \mathrm{~A}\end{array}$ & RS్GFISELPSEEGK & -3.20 & $2.47 \mathrm{E}-02$ & S-968 & 216.75 \\
\hline Q9Y446 & PKP3 & Plakophilin-3 & $\underline{\mathbf{T} L Q R L S S G F D D I D L P S A V K}$ & -3.16 & $3.50 \mathrm{E}-02$ & $\mathrm{~T}-308$ & 127.41 \\
\hline Q13177 & PAK2 & $\begin{array}{l}\text { Serine/threonine- } \\
\text { protein kinase PAK } \\
2\end{array}$ & YLSEFTPPEK & -3.04 & $4.94 \mathrm{E}-03$ & S-141 & 166.29 \\
\hline Q9Y5K6 & CD2AP & $\begin{array}{l}\text { CD2-associated } \\
\text { protein }\end{array}$ & $\underline{\mathbf{s} V D F D S L T V R}$ & -2.78 & $4.62 \mathrm{E}-03$ & S-458 & 177.1 \\
\hline Q00587 & CDC42EP1 & $\begin{array}{l}\text { Cdc42 effector } \\
\text { protein } 1\end{array}$ & NAIISLPQLNQAAYDSLWGK & -2.68 & 8.80E-06 & S-121 & 249.25 \\
\hline P46937 & YAP1 & $\begin{array}{l}\text { Transcriptional } \\
\text { coactivator YAP1 }\end{array}$ & ISQ $\underline{S} A P V K$ & -2.67 & 3.81E-04 & S-276 & 112.64 \\
\hline
\end{tabular}

$\mathrm{TiO}_{2}$ enrichment (Figure 2C). Around 82.6\% of the identified phosphopeptides were monophosphorylated, while $16.3 \%$ were double phosphorylated and about $1 \%$ was multiphosphorylated (Figure 2D). About $80 \%$ of the phosphate moieties were located at serine residues, $19 \%$ at threonine residues and only less than $1 \%$ at tyrosine residues (Figure 2E). The analysis of phosphorylation motifs of all regulated phosphosites revealed the consensus sequence R/X-X-S-P and S-P for phosphoserine and T-P for phosphothreonine (data not shown).

The quality of data was supported by a principle component analysis (PCA) of all phosphopeptides identified in the 3 replicates (Figure $\mathbf{3 A}$ ). Each possible comparison (TcdB/Control; $\mathrm{TcdB}_{\mathrm{NXN}} /$ Control; $\mathrm{TcdB} / \mathrm{TcdB}_{\mathrm{NXN}}$ ) clustered properly showing the reproducibility of the fractionation and enrichment method. 
A

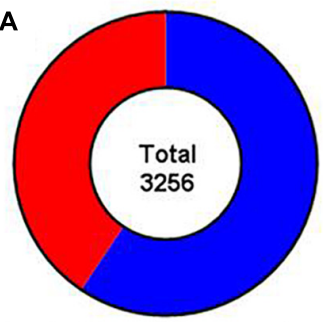

$59.40 \%$ phosphorylated

$40.60 \%$ non-phosphorylated
B

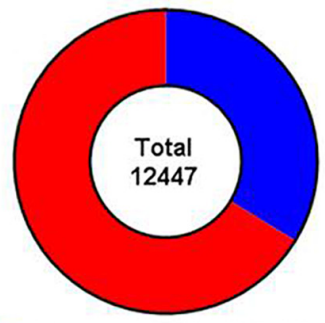

$33.72 \%$ phosphorylated

$66.28 \%$ non-phosphorylated
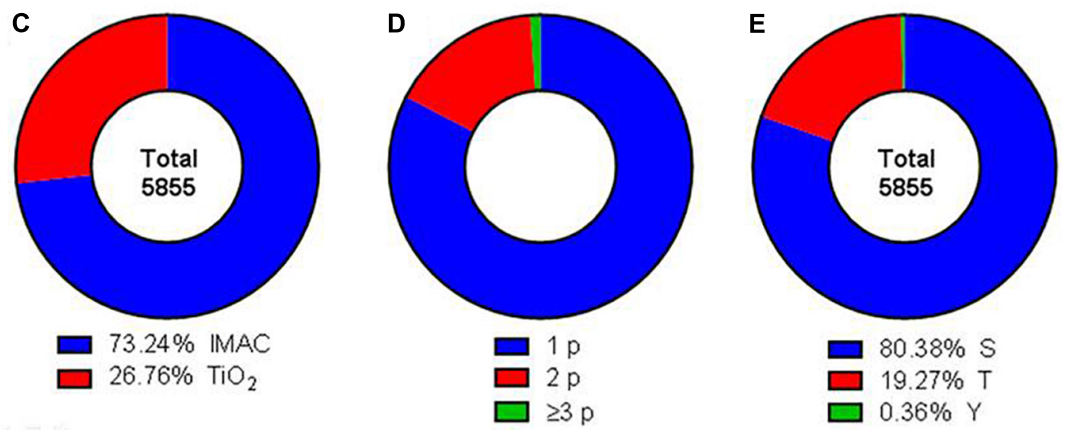

FIGURE 2 | Comprehensive characterization of the obtained dataset. Donut charts illustrating the percentage of identified phosphorylated and non-phosphorylated proteins (A) and peptides (B). Red areas represent phosphorylated peptides and proteins, blue areas not phosphorylated proteins and peptides. (C) Total phosphopeptides have been enriched using IMAC (blue) or TiO2 (red) techniques. (D) Identified phosphopeptides contained either one (blue), two (red), or three or more (green) phosphor groups. (E) Phosphorylation was detected at serine (blue), threonine (red), and tyrosine (green) residues.
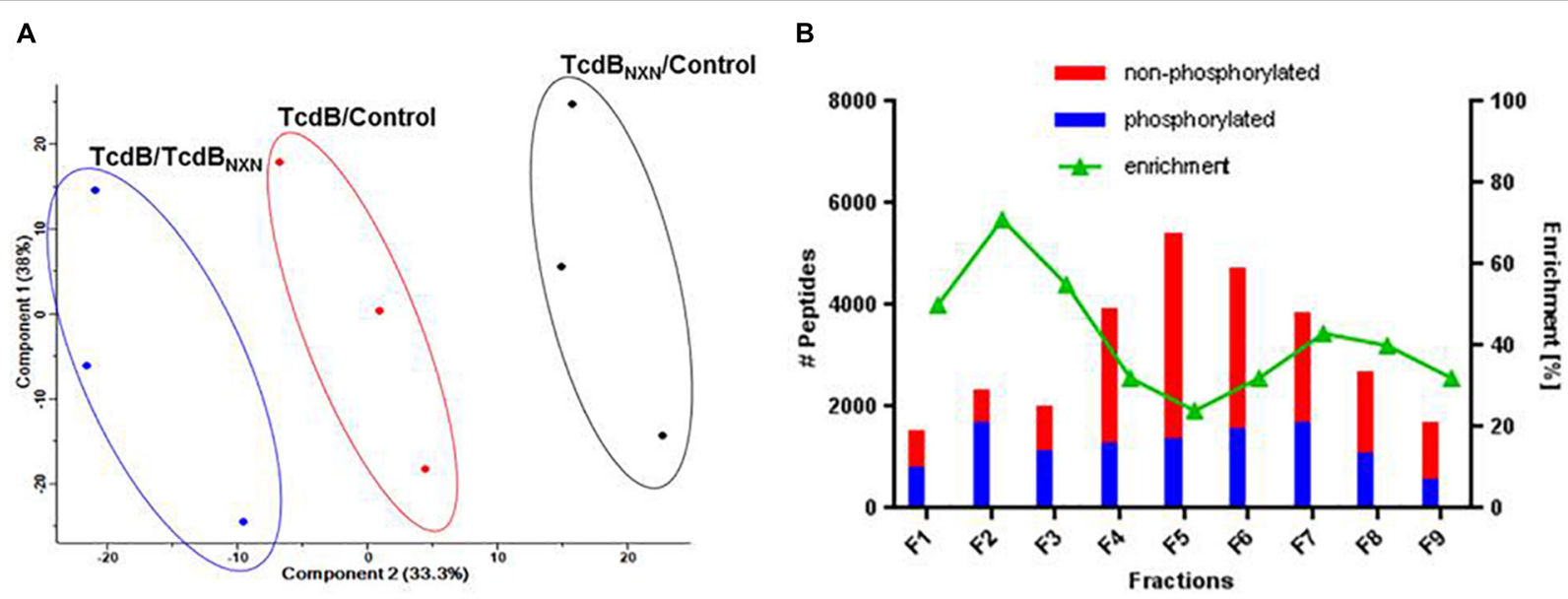

FIGURE 3 | Data reproducibility and phosphopeptide enrichment method analysis. (A) Principal component analysis of SILAC labeled replicates illustrating the workflow reproducibility. (B) Histogram showing the distribution of identified phosphorylated and non-phosphorylated peptides and the percentage of enrichment across each fraction of SCX chromatography.

All SCX fractions contributed to the total quantity of identified phosphopeptides (Figure 3B). Especially in the first three fractions more than $50 \%$ of the identified peptides contained a phosphate moiety. In contrast, the middle fractions contained mainly non-phosphorylated peptides, while the amount of phosphorylated peptides remained comparatively constant across all fractions. The number of identified peptides was highest in fraction 5 and declined continuously to fraction 9 .
The comparison of $\mathrm{TcdB}$ vs. control revealed in total 4,336 class-I-phosphosites with a localization probability higher than $75 \%$. The number of identified phosphosites was 3,697 for replicate 1, 2,914 for replicate 2 and 3,112 for replicate 3 (Figure 4A). 2,197 phosphosites were identified in all the replicates, resulting in a reproducibility of $50.7 \%$. The comparison of $\mathrm{TcdB}_{\mathrm{NXN}}$ vs. control resulted in very similar numbers (data not shown). Phosphosites had to be identified 

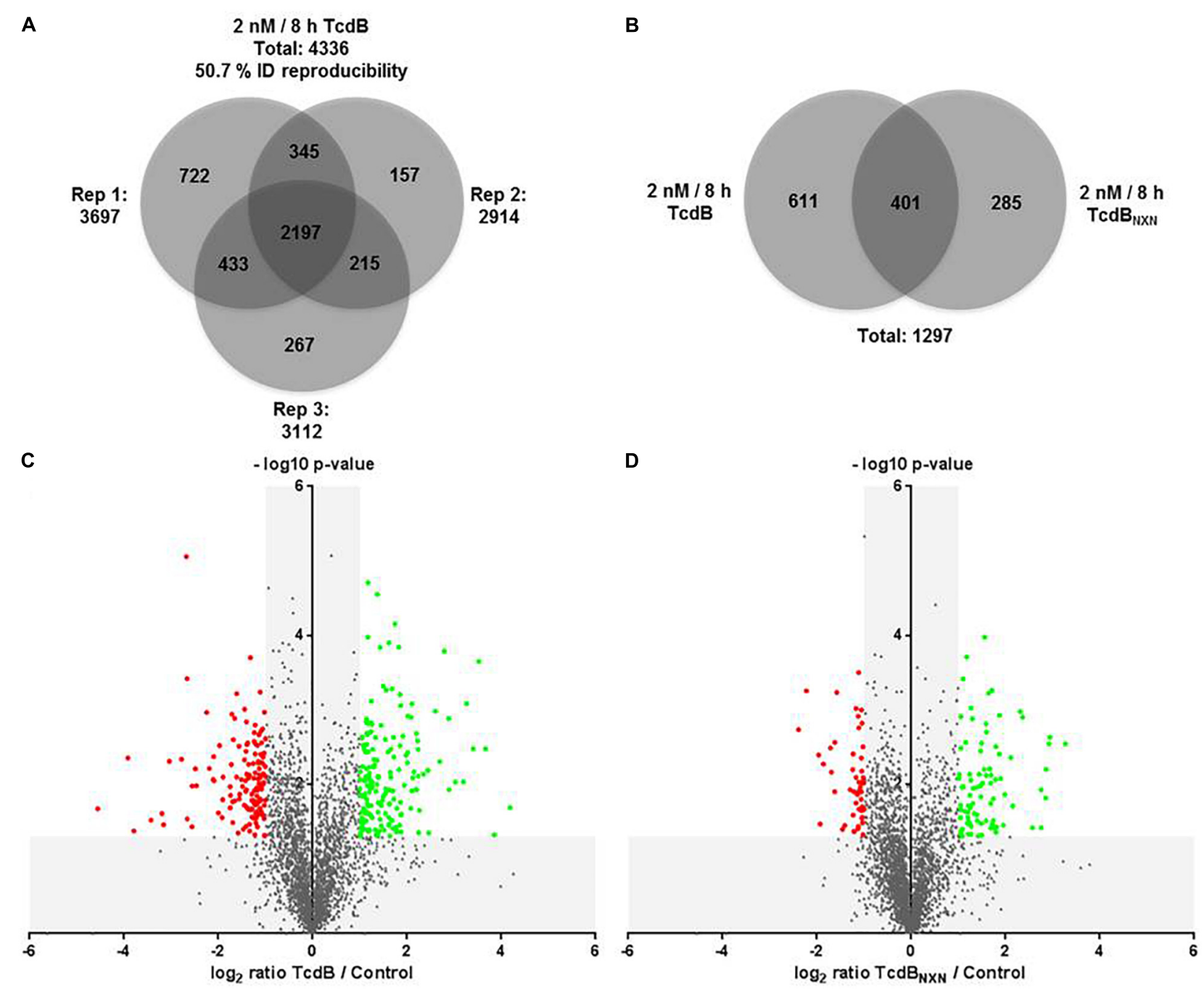

FIGURE 4 | Phosphoproteome analysis of TcdB or TcdB $\mathrm{NXN}_{\text {N }}$ treated HEp-2 cells. (A) Venn diagram of all identified phosphosites with a localization probability higher than $75 \%$ for all three replicates. (B) Venn diagram of all significantly regulated phosphosites as consequence of TcdB or TcdB $\mathrm{NXN}_{\mathrm{N}}$ treatment. Volcano plots of TcdB

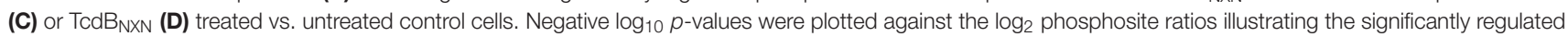
sites (red dots: down-regulation; green dots: up-regulation) with a minimum fold change of 2 and a $p$-value less than 0.05.

in at least two replicates in order to be considered for quantification.

TcdB treatment for $8 \mathrm{~h}$ with $2 \mathrm{nM}$ led in total to 1,012 significantly altered phosphosites, whereas $\mathrm{TcdB}_{\mathrm{NXN}}$ treatment resulted in 686 changed phosphosites. The overlap was 401 phosphosites, while 611 and 285 were altered exclusively by TcdB or $\mathrm{TcdB}_{\mathrm{NXN}}$, respectively (Figure 4B). When taking only phosphosites with a biological relevance with a fold change of at least 2 into account, 177 up-regulated and 141 downregulated sites after $\mathrm{TcdB}$ treatment were obtained. In case of $\operatorname{TcdB}_{\mathrm{NXN}} 86$ phosphosites were up-regulated and 53 downregulated. It is noticeable that more phosphosites exhibited a stronger phosphorylation than vice versa indicating a general stronger activation of phosphoproteins (Figures 4C,D).

The 10 most up- and down-regulated phosphosites with the corresponding proteins and genes are presented in Table $\mathbf{1}$ for
TcdB and Table 2 for $\operatorname{TcdB}_{\mathrm{NXN}}$ treatment. It can be noted that the regulation factors were much higher as a consequence of TcdB treatment than after $\operatorname{TcdB}_{\mathrm{NXN}}$ treatment. The highest up-regulated phosphosite in case of TcdB was S-63 of the transcription factor AP-1 with a fold change (fc) of 18.1, while $\mathrm{TcdB}_{\mathrm{NXN}}$ treatment led to an up-regulation of phosphosite at S-208 of Serine/arginine-rich splicing factor $2(\mathrm{fc}=9.6)$. The most down-regulated phosphosites was S-5448 of neuroblast differentiation-associated protein AHNAK $(\mathrm{fc}=-23.6)$ in case of TcdB and a doubly phosphorylated peptide of $40 \mathrm{~S}$ ribosomal protein S6 (S-236; T-241) with a fold change of -5.2 after $\mathrm{TcdB}_{\mathrm{NXN}}$ treatment. Interestingly, 4 more phosphorylated peptides of 40S ribosomal protein S6 were highly down-regulated. When looking at TcdB it is noticeable that many GTPase effector or regulation proteins and transcription factors enclose the most strongly regulated phosphopeptides. 
TABLE 2 | Top 10 up- and down-regulated phosphosites after $8 \mathrm{~h}$ treatment with TcdB $\mathrm{NXN}_{\text {. }}$.

\begin{tabular}{|c|c|c|c|c|c|c|c|}
\hline Uniprot ID & Gene name & Protein name & Peptide sequence & $\begin{array}{c}\log _{2} \text { Ratio } \\
\text { TcdB } \\
\text { NXN } / \text { control }\end{array}$ & $p$-Value & Amino acid & Peptide score \\
\hline Q01130 & SRSF2 & $\begin{array}{l}\text { Serine/arginine-rich } \\
\text { splicing factor } 2\end{array}$ & SKSPPKSPEEEGAVSS & 3.27 & 2.84E-03 & S-208 & 93.196 \\
\hline 014974 & PPP1R12A & $\begin{array}{l}\text { Protein phosphatase } \\
1 \text { regulatory subunit } \\
12 \mathrm{~A}\end{array}$ & RLASTSSDIEEK & 2.94 & 2.33E-03 & S-507 & 142.95 \\
\hline Q09666 & AHNAK & $\begin{array}{l}\text { Neuroblast } \\
\text { differentiation- } \\
\text { associated protein } \\
\text { AHNAK }\end{array}$ & LKSEDGVEGDLGETQSR & 2.92 & 2.85E-03 & S-135 & 255.63 \\
\hline Q8WX93 & PALLD & Palladin & IASEDEIQGTK & 2.86 & $6.28 \mathrm{E}-03$ & S-893 & 181.75 \\
\hline 094906 & PRPF6 & $\begin{array}{l}\text { Pre-mRNA- } \\
\text { processing factor } \\
6\end{array}$ & LSQVSDSVSGQITVDPK & 2.85 & $1.53 \mathrm{E}-02$ & $\mathrm{~T}-266$ & 143.47 \\
\hline P16989 & YBX3 & $\begin{array}{l}\text { Y-box-binding protein } \\
3\end{array}$ & sVVGDGETVEFDWVEGEK & 2.75 & 1.18E-02 & S-102 & 149.44 \\
\hline Q8IVT2 & MISP & $\begin{array}{l}\text { Mitotic interactor and } \\
\text { substrate of PLK1 }\end{array}$ & HLㅌESSGKPLSTK & 2.75 & 3.82E-02 & S-471 & 144.41 \\
\hline G5E9C8 & SOS1 & $\begin{array}{l}\text { Son of sevenless } \\
\text { homolog } 1\end{array}$ & SAㅁSSISLTK & 2.57 & 3.82E-02 & S-1119 & 81.789 \\
\hline E9PFD7 & EGFR & $\begin{array}{l}\text { Receptor } \\
\text { protein-tyrosine } \\
\text { kinase }\end{array}$ & ELVEPLIPPSGEAPNQALLR & 2.36 & $1.26 \mathrm{E}-03$ & $\mathrm{~T}-648$ & 218.81 \\
\hline P29966 & MARCKS & $\begin{array}{l}\text { Myristoylated } \\
\text { alanine-rich C-kinase } \\
\text { substrate }\end{array}$ & GEPAAAAAPEAGAㅍVEK & 2.31 & 1.05E-03 & S-101 & 185.3 \\
\hline P62753 & RPS6 & $\begin{array}{l}40 S \text { ribosomal } \\
\text { protein } 56\end{array}$ & LSSLRASTSKSESSQK & -2.39 & $1.84 \mathrm{E}-03$ & S-236;T-241 & 112.12 \\
\hline P62753 & RPS6 & $\begin{array}{l}40 S \text { ribosomal } \\
\text { protein S6 }\end{array}$ & RLSSLR & -2.23 & 5.54E-04 & S-235;S-236 & 126.16 \\
\hline P62753 & RPS6 & $\begin{array}{l}40 S \text { ribosomal } \\
\text { protein } 56\end{array}$ & RLSSSLR & -1.97 & 4.04E-03 & S-235 & 126.16 \\
\hline P62753 & RPS6 & $\begin{array}{l}40 S \text { ribosomal } \\
\text { protein S6 }\end{array}$ & RLS $\underline{S} L R$ & -1.93 & 3.41E-02 & S-236 & 126.16 \\
\hline P62753 & RPS6 & $\begin{array}{l}40 S \text { ribosomal } \\
\text { protein } 56\end{array}$ & RLSSLRASITSK & -1.86 & 5.35E-03 & S-240 & 125.84 \\
\hline Q9UQ35 & SRRM2 & $\begin{array}{l}\text { Serine/arginine } \\
\text { repetitive matrix } \\
\text { protein } 2\end{array}$ & SSRSS्PELTRK & -1.71 & $3.25 \mathrm{E}-03$ & S-1694 & 110.55 \\
\hline AOAOAOMT60 & FKBP15 & $\begin{array}{l}\text { Peptidyl-prolyl } \\
\text { cis-trans isomerase }\end{array}$ & SSL్GDEEDELFK & -1.69 & 6.89E-03 & S-1189 & 175.27 \\
\hline G3V160 & CNKSR1 & $\begin{array}{l}\text { Connector enhancer } \\
\text { of kinase suppressor } \\
\text { of ras } 1\end{array}$ & SPSLSLAPLㅍR & -1.62 & 1.26E-02 & S-49 & 118.2 \\
\hline Q92797 & SYMPK & Symplekin & $\begin{array}{l}\text { SPQTLAPVGE } \\
\text { DAMKTP } \underline{S} P A A E D A R E P E A K\end{array}$ & -1.62 & 2.73E-03 & S-1259 & 111.09 \\
\hline A0A096LNZO & AAK1 & $\begin{array}{l}\text { Uncharacterized } \\
\text { protein FLJ45252 }\end{array}$ & LGGAVPFAPPEVㅁPEQAK & -1.58 & $5.82 \mathrm{E}-04$ & S-217 & 130.37 \\
\hline
\end{tabular}

\section{DISCUSSION}

For the first time the effects of $\mathrm{TcdB}$ or glucosyltransferase deficient mutant $\mathrm{TcdB}_{\mathrm{NXN}}$ on the phosphoproteome of target cells were examined. C. difficile toxins inhibit small GTPases of the Rhoand Ras-family by glucosylation leading to perturbation of affected signaling pathways and subsequent actin cytoskeleton breakdown. Since protein phosphorylation plays an important role in signaling pathways a phosphoproteome approach has been chosen to reveal further insights into GTPase down-stream processes induced by C. difficile toxins (Stasyk and Huber, 2012). A SILAC approach was chosen to precisely quantify the toxin-induced effects in HEp2 cells which show a clear pyknotic phenotype. Phosphopeptides were enriched by a combination of IMAC and $\mathrm{TiO}_{2}$ materials prior to LC-MS shotgun analysis which is an approved strategy to detect as much phosphopeptides as possible. 
With the chosen setup 4,197 phosphorylated peptides containing 5,855 phosphosites were identified. Of these phosphosites 4,336 had a localization probability higher than $75 \%$ and therefore were qualified for quantification (Figure 2). Overall 1,297 phosphosites were significantly altered due to TcdB or $\mathrm{TcdB}_{\mathrm{NXN}}$ treatment $(2 \mathrm{nM}$ for $8 \mathrm{~h}$ ) (Figure 4). Interestingly, the glucosyltransferase deficient $\mathrm{TcdB}_{\mathrm{NXN}}$ had a strong impact on the phosphoproteome. These effects should be independent from inactivation of small GTPases by glucosylation. In previous proteome studies a strong input on proteome homeostasis has been observed for $\mathrm{TcdB}_{\mathrm{NXN}}$ treated cells indicating glucosyltranferase-independent activities of TcdB (Erdmann et al., 2017). Glucosyltransferase active TcdB induces, as expected, cell rounding due to cytoskeleton rearrangement in about $80 \%$ of Hep- 2 cells and a pyknotic morphology; in the remaining $20 \%$ of cells.

All significantly regulated phosphopeptides were compared and many showed a consensus sequence of a clearly prolinedependent phosphorylation sites (S/T-P), which are the target motifs of MAP and cyclin-dependent kinases (Bobo et al., 2013). This correlates well with earlier observations in which it has been reported that apoptosis induced by TcdB is mediated by MAPK-dependent caspase activation (Trost et al., 2009).

The treatment with the enzymatically active TcdB led to generally stronger regulated phosphosites with higher fold changes (Figure 4B and Tables 1, 2). Interestingly, the majority of altered p-sites were up-regulated indicating an activation of signaling transduction pathways as a result of treatment with a glucosyltransferase-active toxin. When looking at the top 10 up- and down-regulated proteins it is noticeable that the phosphorylation status of many GTPase effector proteins and GEFs such as Cdc42 effector protein 1/4 and Arhgef2 and Dock 5 were altered after TcdB treatment. As expected this was not the case for $\mathrm{TcdB}_{\mathrm{NXN}}$. Also AP-1 transcription factor phosphorylation sites were highly phosphorylated, which is a downstream factor of p38 and JNK signaling pathways and is activated as a result of stress and apoptosis (Nateri et al., 2004; Wang et al., 2007). In case of $\mathrm{TcdB}_{\mathrm{NXN}}$ treatment many cytoskeleton and cell proliferation regulators like PPP1R12A and SRSF2 phosphorylation sites were up-regulated. The SRSF2 protein is known to be phosphorylated in response to apoptosis (Edmond et al., 2011). The 40S ribosomal protein S6 phosphopeptides were strongly downregulated (Table 2). This ribosomal subunit is involved in cell growth and proliferation by mTOR signaling pathway and is dephosphorylated at growth arrest (Magnuson et al., 2012).

Phosphosites with MAP kinase motifs were differently regulated in TcdB and TcdBNXN. These kinases are particular

\section{REFERENCES}

Bobo, L. D., El Feghaly, R. E., Chen, Y. S., Dubberke, E. R., Han, Z., Baker, A. H., et al. (2013). Mapk-activated protein kinase 2 contributes to clostridium difficile-associated inflammation. Infect. Immun. 81, 713-722. doi: 10.1128/IAI. 00186- 12

Chaves-Olarte, E., Weidmann, M., Eichel-Streiber, C., and Thelestam, M. (1997). Toxins $\mathrm{A}$ and $\mathrm{B}$ from clostridium difficile differ with respect to enzymatic involved in ERK, JNK und p38 signaling pathways (Pearson et al., 2001). Several proteins belonging to these pathways have been identified in a proteome analysis to be regulated in similar treated cells (Junemann et al., 2016). Particularly RAF activators and transcription factors, e.g., AP-1 localized downstream of JNK signaling are involved. These pathways regulates apoptotic processes and cell cycle arrest (Dhanasekaran and Reddy, 2008, Huang et al., 2009). These hypothesis are supported by further studies that provide evidence for a caspasemediated apoptosis induced by C. difficile toxins (Qa'Dan et al., 2002; Solomon et al., 2005; Nottrott et al., 2007). First an activation of inhibitory caspases 8 and 9 is induced with an subsequent activation of known effector caspases 3, 6, and 7 that are involved in the cytotoxic effects induced by $\mathrm{C}$. difficile toxins.

At a first glance these preliminary results suggest signaling pathways to be affected by $\mathrm{TcdB}$ or $\mathrm{TcdB}_{\mathrm{NXN}}$ treatment. Nevertheless, further investigations are necessary to further elaborate and confirm these findings.

\section{AUTHOR CONTRIBUTIONS}

AP conceived the idea. JJ performed the experiments. JJ, AP, and RG did data analyses. JJ, RG, IJ, and AP wrote the manuscript and approved the final version.

\section{FUNDING}

This work was partially funded by the Federal State of Lower Saxony, Niedersächsisches Vorab (VWZN2889).

\section{ACKNOWLEDGMENTS}

We are grateful to Ulrike Schrameck, Helma Tatge, and Karsten Heidrich for excellent technical assistance.

\section{SUPPLEMENTARY MATERIAL}

The Supplementary Material for this article can be found online at: https://www.frontiersin.org/articles/10.3389/fmicb. 2018.03083/full\#supplementary-material

TABLE S1 | Identified proteins.

TABLE S2 | Identified phosphopeptides.

potencies, cellular substrate specificities, and surface binding to cultured cells. J. Clin. Invest. 100, 1734-1741. doi: 10.1172/JCI119698

Chumbler, N. M., Farrow, M. A., Lapierre, L. A., Franklin, J. L., and Lacy, D. B. (2016). Clostridium difficile toxins $\mathrm{Tcd} A$ and $\mathrm{TcdB}$ cause colonic tissue damage by distinct mechanisms. Infect. Immun. 84, 2871-2877. doi: 10.1128/IAI. 00583-16

Cox, J., and Mann, M. (2008). Maxquant enables high peptide identification rates, individualized p.p.b.-range mass accuracies and proteome-wide 
protein quantification. Nat. Biotechnol. 26, 1367-1372. doi: 10.1038/ nbt.1511

Cox, J., and Mann, M. (2012). 1D and 2D annotation enrichment: a statistical method integrating quantitative proteomics with complementary highthroughput data. BMC Bioinform. 13:S12. doi: 10.1186/1471-2105-13-S16-S12

Cox, J., Neuhauser, N., Michalski, A., Scheltema, R. A., Olsen, J. V., and Mann, M. (2011). Andromeda: a peptide search engine integrated into the MaxQuant environment. J. Proteome Res. 10, 1794-1805. doi: 10.1021/pr101065j

Dhanasekaran, D. N., and Reddy, E. P. (2008). JNK signaling in apoptosis. Oncogene 27, 6245-6251. doi: 10.1038/onc.2008.301

Edmond, V., Moysan, E., Khochbin, S., Matthias, P., Brambilla, C., Brambilla, E., et al. (2011). Acetylation and phosphorylation of SRSF2 control cell fate decision in response to cisplatin. EMBO J. 30, 510-523. doi: 10.1038/emboj. 2010.333

Erdmann, J., Junemann, J., Schröder, A., Just, I., Gerhard, R., and Pich, A. (2017). Glucosyltransferase dependent and independent effects of TcdB on the proteome of HEp-2 cells. Proteomics 17, 15-21. doi: 10.1002/pmic.201600435

Farrow, M. A., Chumbler, N. M., Lapierre, L. A., Franklin, J. L., Rutherford, S. A., Goldenring, J. R., et al. (2013). Clostridium difficile toxin B-induced necrosis is mediated by the host epithelial cell NADPH oxidase complex. Proc. Natl. Acad. Sci. U.S.A. 110, 18674-18679. doi: 10.1073/pnas.131 3658110

Frädrich, C., Beer, L. A., and Gerhard, R. (2016). Reactive oxygen species as additional determinants for cytotoxicity of clostridium difficile toxins $\mathrm{A}$ and B. Toxins 8:E25. doi: 10.3390/toxins 8010025

Genth, H., Pauillac, S., Schelle, I., Bouvet, P., Bouchier, C., Varela-Chavez, C., et al. (2014). Haemorrhagic toxin and lethal toxin from Clostridium sordellii strain vpi9048: molecular characterization and comparative analysis of substrate specificity of the large clostridial glucosylating toxins. Cell. Microbiol. 16, 1706-1721. doi: $10.1111 / \mathrm{cmi} .12321$

Halabi-Cabezon, I., Huelsenbeck, J., May, M., Ladwein, M., Rottner, K., Just, I., et al. (2008). Prevention of the cytopathic effect induced by clostridium difficile toxin B by active Rac1. FEBS Lett. 582, 3751-3756. doi: 10.1016/j.febslet.2008.10.003

Huang, G., Shi, L. Z., and Chi, H. (2009). Regulation of JNK and p38 MAPK in the immune system: signal integration, propagation and termination. Cytokine 48, 161-169. doi: 10.1016/j.cyto.2009.08.002

Jochim, N., Gerhard, R., Just, I., and Pich, A. (2014). Time-resolved cellular effects induced by TcdA from clostridium difficile. Rapid Commun. Mass Spectrom. 28, 1089-1100. doi: 10.1002/rcm.6882

Junemann, J., Birgin, G., Erdmann, J., Schröder, A., Just, I., Gerhard, R., et al. (2016). Toxin A of the nosocomial pathogen clostridium difficile induces primary effects in the proteome of HEp-2 cells. Proteomics Clin. Appl. 11, 3-14. doi: $10.1002 /$ prca.201600031

Just, I., and Gerhard, R. (2004). Large clostridial cytotoxins. Rev. Physiol. Biochem. Pharmacol. 152, 23-47. doi: 10.1007/s10254-004-0033-5

Just, I., Selzer, J., Wilm, M., von Eichel-Streiber, C., Mann, M., and Aktories, K. (1995). Glucosylation of Rho proteins by clostridium difficile toxin B. Nature 375, 500-503. doi: 10.1038/375500a0

Kuehne, S. A., Cartman, S. T., Heap, J. T., Kelly, M. L., Cockayne, A., and Minton, N. P. (2010). The role of toxin A and toxin B in clostridium difficile infection. Nature 467, 711-713. doi: 10.1038/nature09397

Loo, V. G., Poirier, L., Miller, M. A., Oughton, M., Libman, M. D., Michaud, S., et al. (2005). A Predominantly clonal multi-institutional outbreak of clostridium difficile-associated diarrhea with high morbidity and mortality. N. Engl. J. Med. 353, 2442-2449. doi: 10.1056/NEJMoa051639

Lössner, C., Warnken, U., Pscherer, A., and Schnölzer, M. (2011). Preventing arginine-to-proline conversion in a cell-line-independent manner during cell cultivation under stable isotope labeling by amino acids in cell culture (SILAC) conditions - 1-s2.0-S000326971100025X-main.pdf. Anal. Biochem. 412, 123125. doi: 10.1016/j.ab.2011.01.011

Magnuson, B., Ekim, B., and Fingar, D. C. (2012). Regulation and function of ribosomal protein S6 kinase (S6K) within mTOR signalling networks. Biochem. J. 441, 1-21. doi: 10.1042/BJ20110892

Matarrese, P., Falzano, L., Fabbri, A., Gambardella, L., Frank, C., Geny, B., et al. (2007). Clostridium difficile toxin B causes apoptosis in epithelial cells by thrilling mitochondria: involvement of ATP-sensitive mitochondrial potassium channels. J. Biol. Chem. 282, 9029-9041. doi: 10.1074/jbc.M607 614200
Nateri, A. S., Riera-Sans, L., Da Costa, C., and Behrens, A. (2004). The ubiquitin ligase SCFFbw7 antagonizes apoptotic JNK signaling. Science 303, 1374-1378. doi: $10.1126 /$ science. 1092880

Nottrott, S., Schoentaube, J., Genth, H., Just, I., and Gerhard, R. (2007). Clostridium difficile toxin A-induced apoptosis is p53-independent but depends on glucosylation of Rho GTPases. Apoptosis 12, 1443-1453. doi: 10 . 1007/s10495-007-0074-8

Olling, A., Goy, S., Hoffmann, F., Tatge, H., Just, I., and Gerhard, R. (2011). The repetitive oligopeptide sequences modulate cytopathic potency but are not crucial for cellular uptake of clostridium difficile toxin A. PLoS One 6:e17623. doi: 10.1371/journal.pone.0017623

Ong, S. E., Blagoev, B., Kratchmarova, I., Kristensen, D. B., Steen, H., Pandey, A., et al. (2002). Stable isotope labeling by amino acids in cell culture, SILAC, as a simple and accurate approach to expression proteomics. Mol. Cell. Proteomics 1, 376-386. doi: 10.1074/mcp.M200025-MCP200

Pearson, G., Robinson, F., Beers Gibson, T., Xu, B., Karandikar, M., Berman, K., et al. (2001). Mitogen-activated protein (map) kinase pathways: regulation and physiological functions 1. Endocr. Rev. 22, 153-183. doi: 10.1210/er.22.2.153

Qa’Dan, M., Ramsey, M., Daniel, J., Spyres, L. M., Safiejko-Mroczka, B., OrtizLeduc, W., et al. (2002). Clostridium difficile toxin B activates dual caspasedependent and caspase-independent apoptosis in intoxicated cells. Cell. Microbiol. 4, 425-434. doi: 10.1046/j.1462-5822.2002.00201.x

Reinert, D. J., Jank, T., Aktories, K., and Schulz, G. E. (2005). Structural basis for the function of clostridium difficile toxin B. J. Mol. Biol. 351, 973-981. doi: 10.1016/j.jmb.2005.06.071

Shannon, P., Markiel, A., Ozier, O., Baliga, N. S., Wang, J. T., Ramage, D., et al. (2003). Cytoscape: a software environment for integrated models of biomolecular interaction networks. Genome Res. 13, 2498-2504. doi: 10.1101/ gr.1239303

Solomon, K., Webb, J., Ali, N., Robins, R. A., and Mahida, Y. R. (2005). Monocytes are highly sensitive to clostridium difficile toxin A-induced apoptotic and nonapoptotic cell death. Infect. Immun. 73, 1625-1634. doi: 10.1128/IAI.73.3. 1625-1634.2005

Stasyk, T., and Huber, L. A. (2012). Mapping in vivo signal transduction defects by phosphoproteomics. Trends Mol. Med. 18, 43-51. doi: 10.1016/j.molmed.2011. 11.001

Trost, M., English, L., Lemieux, S., Courcelles, M., Desjardins, M., and Thibault, P. (2009). The phagosomal proteome in interferon- $\gamma$-activated macrophages. Immunity 30, 143-154. doi: 10.1016/j.immuni.2008.11.006

Tyanova, S., Temu, T., Sinitcyn, P., Carlson, A., Hein, M. Y., Geiger, T., et al. (2016). The perseus computational platform for comprehensive analysis of (prote)omics data. Nat. Methods 13, 731-740. doi: 10.1038/nmeth.3901

Voth, D., and Ballard, J. (2005). Clostridium difficile toxins: mechanism of action and role in disease. Clin. Microbiol. Rev. 18, 247-263. doi: 10.1128/CMR.18.2. 247-263.2005

Wang, L., Dai, W., and Lu, L. (2007). Stress-induced c-Jun activation mediated by polo-like kinase 3 in corneal epithelial cells. J. Biol. Chem. 282, 32121-32127. doi: 10.1074/jbc.M702791200

Wohlan, K., Goy, S., Olling, A., Srivaratharajan, S., Tatge, H., Genth, H., et al. (2014). Pyknotic cell death induced by clostridium difficileTcdB: chromatin condensation and nuclear blister are induced independently of the glucosyltransferase activity. Cell. Microbiol. 16, 1678-1692. doi: 10.1111/cmi. 12317

Zeiser, J., Gerhard, R., Just, I., and Pich, A. (2013). Substrate specificity of clostridial glucosylating toxins and their function on colonocytes analyzed by proteomics techniques. J. Proteome Res. 12, 1604-1618. doi: 10.1021/pr300973q

Conflict of Interest Statement: The authors declare that the research was conducted in the absence of any commercial or financial relationships that could be construed as a potential conflict of interest.

Copyright (c) 2018 Junemann, Just, Gerhard and Pich. This is an open-access article distributed under the terms of the Creative Commons Attribution License (CC BY). The use, distribution or reproduction in other forums is permitted, provided the original author(s) and the copyright owner(s) are credited and that the original publication in this journal is cited, in accordance with accepted academic practice. No use, distribution or reproduction is permitted which does not comply with these terms. 